\title{
POPULASI IMAGO Sitophilus oryzae L (Coleoptera: Curculionidae) PADA BEBERAPA JENIS BERAS ASAL DESA WAIMITAL KECAMATAN KAIRATU
}

\author{
Population of Imago of Sitophilus oryzae L (Coleoptera: Curculionidae) on Some types of Rice \\ from Waimital Village Kairatu District
}

\section{Lia A. Booroto ${ }^{1}$, Nureny Goo ${ }^{2 . *}$ dan Saartje H. Noya ${ }^{2}$}

\author{
${ }^{1}$ Program Studi Agroekoteknologi, Jurusan Budidaya Pertanian, Fakultas Pertanian, Universitas Pattimura \\ ${ }^{2}$ Jurusan Budidaya Pertanian, Fakultas Pertanian, Universitas Pattimura \\ Jl. Ir. M. Putuhena, Kampus Poka, Ambon 97233 \\ Penulis korespondensi: E-mail: nureny.goo@faperta.unpatti.ac.id
}

\begin{abstract}
The objective of this study was to determine the population of Sitophilus oryzae imago on rice from 5 varieties of paddy from Waimital Village. The rice used in this research were taken directly from rice mill in Waimital Village. Completely Randomized Design with 5 treatments and 3 replications was used in this study. Two trials were used in this research. The first experiment was to investigate the incidence of imago S. oryzae each week, and the second trial to calculate the population on rice stored for 8 weeks. The results showed that there was a different period of development of S. oryzae every week on five types of rice. While for 8 weeks storage, the highest population of S. oryzae imago was on variety of Inpari 21 with 184.00 beetles, and the lowest was on variety of Cimelati with 64.67 beetles. The population on the other 3 varieties (Mekongga, Ciherang, and IR64) were 176.33, 133.33 and 76.33 respectively.
\end{abstract}

Keywords: pests in storage, rice, Sitophilus oryzae

\begin{abstract}
ABSTRAK
Penelitian ini bertujuan untuk mengetahui populasi imago Sitophilus oryzae pada beras dari 5 varietas padi asal Desa Waimital. Beras yang digunakan dalam penelitian ini adalah beras yang diambil langsung dari tempat penggilingan padi yang ada di Desa Waimital. Penelitian ini menggunakan Rancangan Acak Lengkap dengan 5 perlakuan dan 3 ulangan. Digunakann 2 percobaan, percobaan pertama untuk mengetahui kemunculan imago $S$. oryzae setiap minggu dan percobaan kedua untuk menghitung populasi pada beras yang disimpan selama8 minggu. Hasil penelitian menunjukan bahwa terdapat perbedaan periode perkembangan $S$. oryzae setiap minggu pada kelima jenis beras. Sedangkan selama 8 minggu penyimpanan, populasi imago $S$. oryzae tertinggi pada jenis beras dari varietas Inpari 21 dengan populasi 184,00 kumbang dan terendah pada jenis beras dari varietas, Cimelati dengan populasi 64,67 kumbang. Populasi pada 3 varietas lainnya (Mekongga, Ciherang dan IR64) adalah berturut- turut 176,33 (ekor), 133,33 (ekor) dan 76,33 (ekor).
\end{abstract}

Kata kunci: beras, hama di tempat penyimpanan, Sitophilus oryzae

\section{PENDAHULUAN}

Tanaman padi (Oryza sativa L.) adalah tanaman pangan penghasil beras yang dibutuhkan sebagian besar penduduk dunia. Di Indonesia beras merupakan bahan pangan pokok bagi $90 \%$ penduduk (Yudansha et al., 2013). Laju pertumbuhan Penduduk yang terus meningkat membuat Indonesia terus memacu produksi beras agar dapat memenuhi kebutuhan pangan dan tidak lagi mengimpor beras dari negara lain. Program pemerintah meningkatkan ketahanan pangan nasional dengan target mencapai swasembada pangan pada tahun 2017. Kementrian Pertanian melalui Badan Litbang Pertanian ikut mendukung pencapaian swasembada pangan beras dengan menghasilkan berbagai inovasi teknologi yang mampu meningkatkan produktivitas padi diantaranya penggunaan varietas unggul dan juga mengembangkan pendekatan Pengelolaan Tanaman Terpadu (PTT). Peningkatan swasembada pangan juga dilaksanakan di empat kabupaten di Maluku yang menjadi sentra penanaman padi seperti Kabupaten Maluku Tengah, Buru, Seram Bagian Barat (SBB), dan Seram Bagian Timur (SBT) (Titahena dan Febriyanti, 2015). Namun untuk mencapai sasaran tersebut banyak kendala yang ditemui, salah satu diantaranya adalah faktor penanganan pasca panen yang tidak tepat. Menurut Lopulalan (2010), penyimpanan merupakan salah satu mata rantai pasca panen yang sangat penting. Produk pasca panen merupakan bagian tanaman yang dipanen dengan berbagai tujuan terutama untuk 
memberikan nilai tambah dan keuntungan bagi petani maupun konsumen.

Produk dalam simpanan ini tidak terlepas dari organisme pengganggu terutama dari golongan serangga (Manueke dan Pelealu, 2015). Menurut Wulandari et a., (2014), Hama pada bahan simpanan umumnya merupakan hama langsung, yang dimana kerusakan terjadi langsung pada bahan yang dikonsumsi. Untuk itu perlu diperhatikan prinsip dasar pengendalian hama gudang yang meliputi penanganan dan pengolahan hasil panen, pengelolaan dan sanitasi gudang, manipulasi lingkungan fisik, pemantauan hama, peningkatan ketrampilan dan kemampuan operasional pengelola gudang (Herlina dan Istiaji, 2013).

Salah satu penyebab kerusakan beras di tempat penyimpanan adalah hama kumbang bubuk Sitophilus sp. S. oryzae merupakan hama yang merusak biji-bijian ditempat penyimpanan dan merupakan hama utama pada beras, selain itu juga menyerang jenis pangan lain seperti jagung, gandum, kedelai, kacang tanah, kacang kapri dan kopra (Antika et al, 2014).

Kerusakan akibat hama ini menyebabkan butiran beras berlubang-lubang kecil sehingga mudah pecah dan hancur seperti tepung, jika serangan terus terjadi dapat mengakibatkan kerugian ekonomi baik berupa susut bobot dan susut mutu, seperti penurunan daya kecambah benih, perubahan warna dan rasa, penurunan nilai gizi, serta terkontaminan oleh kotoran dan bagian tubuh serangga (Lopulalan, 2010).

Hasil Penelitian Kamsiati et al., (2013) menunjukan varietas padi berpengaruh nyata terhadap ketahanan beras dari serangan hama gudang $S$. oryzae dan tingkat kerusakan beras selama penyimpanan, dari 8 vareitas lokal di Kalimantan Tengah antara lain, Karang dukuh, Siam jurut, Siam pandak, Siam palun, Siam palas, Bayar pahit, Rantul dan Siam unus. Dari 8 varietas tersebut, varietas Siam jurut paling tahan terhadap serangan $S$. oryzae, dengan susut bobot 4,0650 \% sedangkan varietas Siam pandak dan Karang dukuh yang paling rentan terhadap serangan $S$. oryzae dengan susut bobot $10,3100 \%$ dan $11,7250 \%$.

Hasil penelitian preferensi Sitophilus zeamais pada enam varietas padi (sadang, Banto, IR36, Cikapandang, Cisadane dan IR54 menunjukan bahwa varietas IR54 yang paling disukai dengan rata-rata jumlah imago 63,0 ekor sedangkan varietas sadang kurang disukai dengan jumlah imago 31,0 ekor (Sudarmadji dan Hendarsih, 1987) dalam Sodiq (2009).

Salah satu alternatif pengendalian hama gudang Sitophilus $s p$ yang lebih aman ialah dengan mengembangkan varietas-varietas padi yang tahan terhadap hama tersebut. Upaya seleksi varietas yang tahan terhadap hama ini dapat dikembangkan lebih lanjut dalam kegiatan pemuliaan tanaman (Herlina dan Istiaji, 2013).

Dalam upaya peningkatan swasembada pangan beras di Maluku, maka berdasarkan uraian diatas penulis tertarik untuk meneliti beberapa jenis beras dari varietas padi yang dibudidayakan di Desa Waimital terhadap serangan hama gudang $S$. oryzae.
Penelitian ini bertujuan untuk mengetahui populasi imago Sitophilus oryzae pada beberapa jenis beras asal Desa Waimital. Hipotesis yang diajukan adalah Populasi imago Sitophilus oryzae lebih rendah pada beras varietas Inpari 21

\section{METODE PENELITIAN}

\section{BahanPenelitian}

Bahan yang digunakan dalam penelitian ini antara lain beras dari 5 varietas padi (Mekongga, Ciherang, IR64, Cimelati dan Inpari 21), dan serangga uji imago kumbang beras (Sitophilus oryzae L).

\section{Tempat dan Waktu Penelitian}

Penelitian ini dilaksanakan di Laboratorium Biocontrol Fakultas Pertanian Universitas Pattimura yang berlangsung pada bulan Oktober - Desember 2016.

\section{Metode Penelitian}

Metode yang digunakan dalam penelitian ini adalah Rancangan Acak Lengkap (RAL), dengan perlakuan sebagai berikut:

Mekongga $=100 \mathrm{~g}$ beras varietas padi Mekongga

Ciherang $=100 \mathrm{~g}$ beras varietas padi Ciherang

IR64 $=100 \mathrm{~g}$ beras varietas padi IR64

Cimelati $=100 \mathrm{~g}$ beras varietas padi Cimelati

Inpari21 = $100 \mathrm{~g}$ beras varietas padi Inpari21

Setiap perlakuan diulang $3 \mathrm{kali}$, sehingga didapat 15 satuan percobaan.

Rancangan percobaan yang digunakan adalah rancangan acak lengkap. Dalam penelitian ini Dilakukan dua percobaan. Percobaan I untuk mengetahui kemunculan imago baru setiap minggunya. Percobaan II untuk mengetahui susut bobot dan populasi selama delapan minggu penyimpanan.

\section{Tahapan Pelaksanaan Penelitian}

\section{Persiapan serangga uji}

Dilakukan rearing serangga uji imago $S$. oryzae dari tempat penyimpanan beras, kemudian dipelihara didalam kontainer plastik dan diberi pakan beras. Pemeliharaan dilakukan sampai mendapat keturunan F1 dengan umur S. oryzae yang seragam.

\section{Persiapan Pakan sebagai perlakuan}

Perlakuan pakan yang digunakan yakni beras dari padi varietas Mekongga, Ciherang, IR64, Cimelati dan Inpari 21 yang didapat dari tempat penggilingan yang berada di Desa Waimital Kabupaten Seram Bagian Barat. Pakan tersebut dibersihkan dan dipilih bulir beras yang masih utuh kemdian dilakukan pengukuran kadar air awal dengan alat ukur kadar air (moisture tester, dole 400). 


\section{Penempatan serangga uji}

Beras dari setiap perlakuan ditimbang dengan menggunakan timbangan analitik (Citizen) sebanyak 100 gr dan ditempatkan pada kontener plastik $\left(500 \mathrm{~cm}^{3}\right)$ yang disediakan. Kemudian dilakukan infestasi 5 pasang (jantan/betina) imago $S$. oryzae pada setiap perlakuan. Setelah 3 minggu serangga yang diinfestasi dikeluarkan.

Pada Percobaan I. 15 satuan percobaan digunakan untuk pengamatan populasi imago baru setiap minggu. Pada percobaan II. 15 satuan percobaan digunakan untuk pengamatan populasi akhir dan susut bobot pada minggu ke-8.

\section{Variabel Pengamatan}

\section{Gejala Kerusakan}

Pengamatan gejala kerusakan dilakukan minggu ke-3 setelah infestasi. Gejala yang diamati adalah butiran beras yang berlubang dan adanya sisa-sisa tepung hasil gerekan Imago dan larva.

\section{Jumlah imago baru}

Pada percobaan I Imago baru diamati dan dihitung minggu ke-4 setelah infestasi dengan interval waktu seminggu sekali sampai selesai pengamatan, setiap minggunya beras dikeluarkan dan dihitung imago baru yang muncul.

Pada Percobaan II Imago baru diamati dan dihitung setelah 8 minggu infestasi.

\section{Presentase penurunan berat pakan (\%)}

Diamati pada percobaan II. Berat pakan dihitung berat awal sebelum infestasi dan berat akhir setelah selesai pengamatan penelitian, dengan menggunakan rumus yang digunakan (Sutoyo dan Mulyo, 1987) dalam (Wulandari et al., 2014) yaitu:

$$
\mathrm{P}=((\text { berat awal }- \text { berat akhir }) / \text { berat awal }) \times 100 \%
$$

Keterangan : $\mathrm{P}$ adalah presentase penurunan berat $(\%)$

\section{Analisis Data}

Data yang diperoleh kemudian dilakukan analisis keragaman, jika terdapat perbedaan antara perlakuan dilanjutkan dengan Uji Beda (BNJ 0,05\%).

\section{HASIL DAN PEMBAHASAN}

\section{GejalaKerusakan}

Hasil pengamatan gejala kerusakan beras akibat serangan Sitophilus oryzae pada 5 varietas yang mulai diamati minggu ketiga setelah infestasi sampai akhir pengamatan yang dapat dilihat pada gambar berikut:

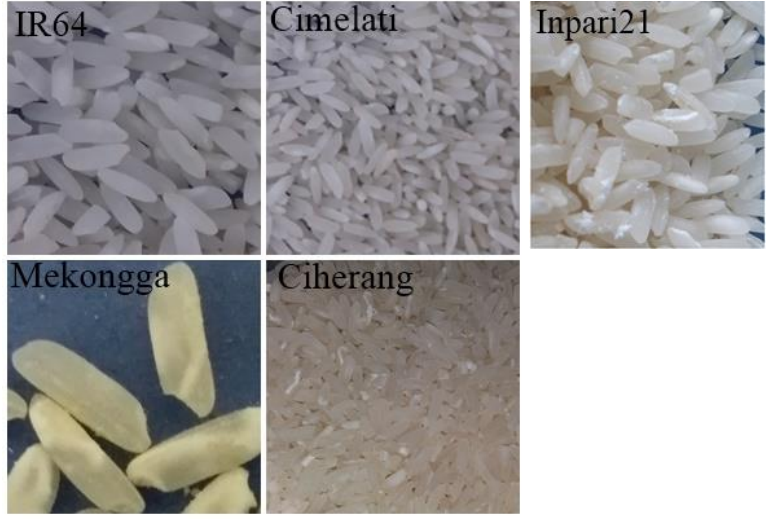

Gambar 1. Kondisi visual butir beras dari 5 varietas padi pada minggu ketiga

Kondisi visual gejala kerusakan akibat serangan Sitophilus oryzae pada 5 varietas padi pada minggu ketiga menunjukan adanya perbedaan gejala kerusakan pada 5 jenis beras tersebut. Pada beras Mekongga, Ciherang dan Inpari21 menunjukan gejala kerusakan seperti butiran beras mulai tampak putih mengapur kemudian terdapat garis putih tak beraturan yang merupakan aktivitas gerekan larva didalam butiran beras, sedangkan pada jenis beras Cimelati dan IR64 belum terlihat gejala seperti pada ketiga varietas lainnya. Kemungkinan bahwa pada Beras Cimelati dan IR64 S. oryzae masih berada pada fase telur.
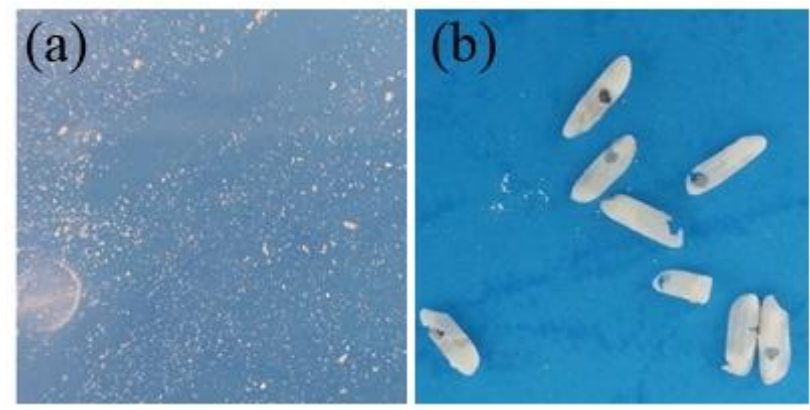

Gambar 2. a) Adanya serbuk pada wadah penyimpanan; dan b) Kerusakan pada butiran beras.

Pada Gambar 2, menunjukan adanya aktivitas makan dari imago $S$. oryzae. serangga ini mulai menggerek butir beras sehingga menghasilkan serbukserbuk halus seperti tepung yang menempel pada wadah penyimpanan. Kemudian setelah memasuki fase telur, larva, dan pupa maka imago baru yang terbentuk didalam butir beras akan keluar melalui lubang yang sudah dibuat sebelumnya, gejala serbuk-serbuk halus mulai terlihat pada minggu ke-4 pengamatan dan gejala butiran beras yang berlubang, retak dan patah, dapat dilihat apabila setiap jenis beras sudah muncul imago baru. Gejala ini terjadi pada semua jenis beras dari tiap varietas padi. 

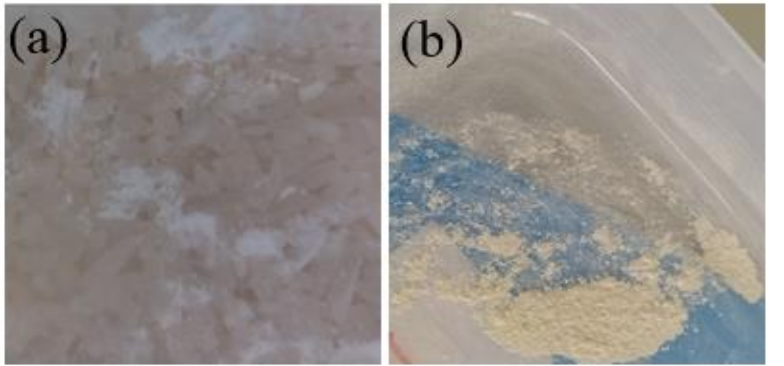

Gambar 3. a) Butir beras mulai hancur; dan b) Serbuk halus seperti tepung

Semakin lama penyimpanan, populasi yang semakin meningkat, juga meningkatkan aktivitas makan S. oryzae maka secara perlahan beras akan hancur seperti bubuk, gejala kerusakan ini dapat dilihat pada gambar (3), gejala ini terlihat jelas pada beras yang disimpan selama 8 minggu untuk semua jenis beras dari tiap varietas. Lopulalan (2010) menyatakan bahwa Kerusakan akibat hama Sitophilus menyebabkan butiran beras berlubang-lubang kecil sehingga mudah pecah dan hancur seperti tepung.

\section{Populasi Imago Sitophilus oryzae Pada Minggu Ke 4, 5, 6, 7 dan 8 Setelah Infestasi}

Pengamatanpopulasi imago $S$. oryzae dimulai pada minggu ke-4 setelah infestasi. Setiap kali pangamatan, imago $S$. oryzae dihitung dan dikeluarkan dari wadah penyimpanan. Beras yang terserang disimpan kembali untuk pengamatan berikutnya sehingga populasi imago yang muncul setiap minggu merupakan imago baru.

Data pada (Tabel 2) menunjukan rata-rata dari total populasi imago Sitophilus oryzae yang muncul pada minggu ke 4, 5, 6, 7 dan 8 setelah infestasi. Setiap minggunya terdapat penambahan populasi imago pada setiap jenis beras.

Kemunculan Imago $S$. oryzae setiap minggunya untuk setiap jenis beras selalu ada pada minggu ke-4 imago sudah mulai muncul untuk kelima jenis beras tetapi berdasarkan uji analisis kerangaman pada (Tabel 3) hasilnya menunjukan bahwa hanya pada pengamatan minggu kelima populasi imago $S$. oryzae pada beras dari varietas Inpari21, Mekongga dan Ciherang berbeda nyata dengan beras dari varietas Cimelati, sedangkan beras dari varietas IR64 dan Cimelati tidak berbedanyata.
Bedasarkan hasil pengamatan gejala kerusakan awal (Gambar 1) menunjukan bahwa fase hidup $S$. oryzae berbeda-beda untuk kelima jenis beras dari tiap varietas padi tersebut. Sehingga memasuki minggu ke-5 pengamatan ada perbedaan populasi imago baru yang muncul pada setiap jenis beras. Hal ini menunjukan bahwa diantara minggu ke-4 dan ke-5 setelah infestasi adalah periode/fase dimana imago baru keluar. Pracaya (2008) dan Rivai (2010) dalam Pertiwi (2011) menyatakan bahwa siklus hidup dari $S$. oryzae yaitu berkisar antara 30-45 hari. Berdasarkan hasil penelitian ini diduga bahwa adanya periode perkembangan $S$. oryzae yang berbeda pada kelima jenis beras tersebut. Dapat dilihat pada (Gambar 4) minggu ke-5 setelah infestasi butiran beras dari varietas Mekongga, Ciherang dan Inpari21 sudah memasuki tahap pupa dewasa, kebanyakan butiran beras berwarna kecoklatan bahkan sudah terdapat imago baru yang keluar, sedangkan pada butiran beras dari varietas IR64 dan Cimelati walaupun terdapat imago baru yang muncul tetapi kebanyakan butir beras masih tampak garis-garis putih, ada butiran tampak putih susu diduga masih berada pada tahap larva atau baru memasuki tahap pupa. Zulfahnur (2010), menyatakan bahwa semakin pendek periode perkembangan maka siklus hidup serangga tersebut semakin cepat dan serangga juga makin cepat berkembang. Kesesuaian makanan juga didugamempengaruhi $S$. oryzaeuntukberkembangbiak. Kondisi visual butiran beras pada minggu ke-5 pada beras dari tiap varieatas dapat dilihat pada Gambar 4 .

Periode perkembangan ini dipengaruhi oleh kadar air awal dari setiap perlakuan, kadar air awal dari beras inpari21 19,7 \% lebih tinggi dibandingkan empat jenis beras dari varietas lainnya. Jenis beras dari varietas Mekongga 19,1\%, Ciherang 19,1\%, IR64 19,0\% dan Cimelati $18,6 \%$. Perbedaan kadar air ini memungkinkan beras melunak dan mudah hancur sehingga $S$. oryzae lebih mudah mengerek dan perkembangannya lebih cepat. Lopulalan (2010) menyatakan bahwa, kadar air yang tinggi pada beras menyebabkan tekstur dari beras menjadi lebih lunak yang akan mempermudah serangga untuk melubangi biji-bijian. Kadar air bahan merupakan faktor penting dalam kelangsungan hidup serangga, semakin tinggi kadar air bahan semakin tinggi tingkat perkembangan serangga.

Tabel 1. Rata-rata Populasi Imago Sitophilus oryzae pada minggu ke 4, 5, 6, 7 dan 8 Setelah Infestasi

\begin{tabular}{lccccc}
\hline \multirow{2}{*}{ Jenis Beras } & \multicolumn{5}{c}{ Minggu ke } \\
\cline { 2 - 6 } & 4 & 5 & 6 & 7 & 8 \\
\hline Mekongga & 3,00 & 11,00 & 21,00 & 46,00 & 69,00 \\
Ciherang & 1,00 & 11,00 & 21,00 & 29,00 & 49,00 \\
IR64 & 2,00 & 7,00 & 12,00 & 15,00 & 12,00 \\
Cimelati & 0,3 & 4,00 & 22,00 & 21,00 & 19,00 \\
Inpari21 & 1,00 & 12,00 & 35,00 & 36,00 & 73,00 \\
\hline
\end{tabular}


Tabel 2. Uji beda Populasi Imago $S$. oryzae Pada Minggu ke-5

\begin{tabular}{lc}
\hline Jenis beras & Rata-rata \\
\hline Inpari21 & $12 \mathrm{a}$ \\
Mekongga & $11 \mathrm{a}$ \\
Ciherang & $11 \mathrm{a}$ \\
IR64 & $7 \mathrm{ab}$ \\
Cimelati & $4 \mathrm{~b}$ \\
\hline BNJ 0,05 & $\mathbf{6 , 4 3}$ \\
\hline
\end{tabular}

Keterangan: Angka yang diikuti dengan huruf yang sama menunjukan tidak beda nyata pada uji BNJ pada taraf $0,05 \%$.

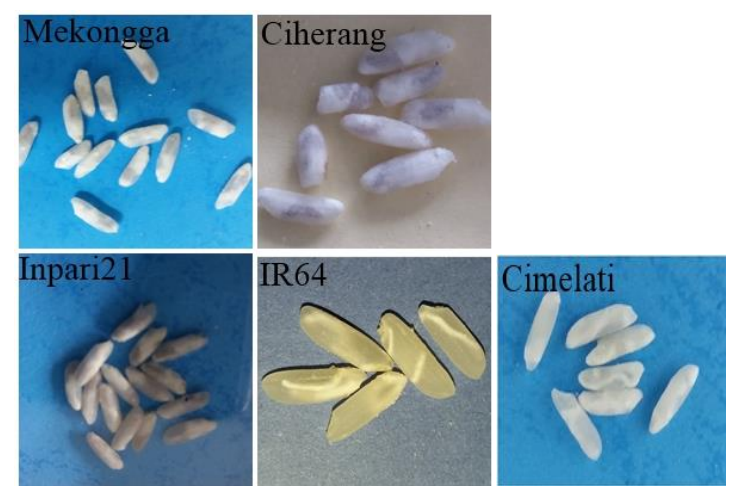

Gambar 4. Kondisi visual butir beras dari setiap varietas padi pada minggu ke-5

\section{Populasi Imago Sitophilus oryzae Selama Delapan Minggu Penyimpanan}

Tabel 3. Rata-rata Populasi Imago Sitophilus oryzae Pada Beras yang disimpan Selama 8 Minggu

\begin{tabular}{lc}
\hline Jenis beras & Rata-rata \\
\hline Inpari21 & $184,00 \mathrm{a}$ \\
\hline Mekongga & $176,33 \mathrm{a}$ \\
\hline Ciherang & $133,33 \mathrm{ab}$ \\
\hline Cimelati & $76,33 \mathrm{~b}$ \\
\hline IR64 & $64.67 \mathrm{~b}$ \\
\hline BNJ 0,5 & $\mathbf{9 3 , 5 2}$ \\
\hline
\end{tabular}

Keterangan: Angka yang diikuti dengan huruf yang sama menunjukan tidak beda nyata pada uji BNJ pada taraf $0,05 \%$.

Hasil pengamatan populasi imago $S$. oryzae pada beras yang disimpan selama 8 minggu menunjukan bahwa rata-rata populasi $S$. oryzae pada beras dari varietas Inpari21, Mekongga, Ciherang, Cimelati dan IR64 menunjukan perbedaan. Populasi tertinggi pada beras dari varietas Inpari21 (184.00) imago $S$. oryzae dan populasi terendah pada beras dari varietas IR64 (64.67) imago $S$. oryzae. Hasil uji beda nyata menunjukan beras dari varietas Inpari21, Mekongga dan Ciherang tidak berbeda nyata, tetapi beras dari varietas Inpari21 dan Mekongga berbeda nyata dengan beras dari varietas Cimelati dan IR64. Sedangkan beras dari varietas
Ciherang, Cimelati dan IR64 tidak berbeda nyata (Tabel 4). Semakin lama beras disimpan maka populasi $S$. oryzae semakin meningkat, semakin banyak bertelur dan menghasilkan imago baru seperti pada Tabel 2, yakni pada pengamatan setiap minggu terdapat penambahan populasi imago S. oryzae. Pasaribu (2009) menyatakan bahwa populasi kumbang beras akan bertambah seiring lamanya penyimpanan dan tingkat kemunculan populasi awal kumbang beras, karena serangga akan meting dan melakukan kopulasi dengan pasangannya sehingga dapat menghasilkan generasi yang lebih banyak, hal ini dipengaruhi oleh kondisi lingkungan terhadap kelangsungan hidup dari S. oryzae. Pada penelitian ini, data rata rata suhu harian berkisar dari $27-29{ }^{\circ} \mathrm{C}$ dan ratarata kelembaban harian berkisar dari 75-79\% kondisi ini sangat sesuai untuk pertumbuhan dan perkembangan Sitophilus oryzae. Yasin (2009) menyatakan bahwa Hama kumbang bubuk Sitophilus sp memerlukan temperatur optimum antara $25^{\circ} \mathrm{C}-30^{\circ} \mathrm{C}$ untuk perkembangannya. Temperatur sangat berpengaruh dalam siklus hidup dari fase telur sampai dewasa. Seperti halnya temperatur, serangga hama Sitophilus sp juga memerlukan kondisi lembab optimum $70 \%$ untuk menopang perkembangbiakannya. Selain faktor suhu dan kelembaban faktor kadar air juga berpengaruh terhadap pertumbuhan dan perkembagan Sitophilus sp. S. oryzae lebih menyukai beras dari jenis Inpari21 karena kadar air awal dari beras 19,7\% lebih tinggi dibandingkan empat jenis beras dari varietas lainnya. Jenis beras dari varietas Mekongga 19,1\%, Ciherang 19,1\%, IR64 19,0\% dan Cimelati $18,6 \%$. Tingginya populasi Imago $S$. oryzae pada beras varietas Inpari21 disebabkan karena kadar air yang tinggi menghasilkan butiran beras menjadi lunak sehingga semakin mudah digerek. Setyolaksono (2013) menyatakan bahwa kadar air yang tinggi akan membuat kondisi lingkungan sesuai untuk perkembangan hama pasca panen, sehingga ketahanan hidup hama tersebut juga meningkat. Kemunculan imago baru setiap minggunya (Tabel 2) juga terjadi pada penyimpanan selama delapan minggu sehingga populasi akhir selama delapan minggu penyimpanan juga meningkat.

\section{Presentase Penurunan Berat Pakan (\%) Selama 8 minggu Penyimpanan}

Kerusakan butiran beras dari setiap jenis beras selama delapan minggu penyimpanan menandakan adanya aktivitas makan, pertumbuhandanperkembangan $S$. oryzae haliniditunjukan dengan adanya penurunan bobot beras dari tiap jenis beras yang dapat dilihat pada (Tabel 5). Yasin (2009) menyatakan kesesuaian makanan berkaitan erat dengan dinamika serangga memilih sumber makanan yang cocok untuk pertumbuhan populasinya atau dalam proses perkembangbiakan keturunannya.

Kandungan amilosa dalam beras adalah salah satu komposisi kimia yang dibutuhkan $S$. oryzae. Kandungan amilosa dari beras tiap varietas berbeda beda, hal ini diduga mempengaruhi untuk pertumbuhan dan perkembangannya $S$. oryzae. Beras dari padi varietas 
Mekongga memiliki kadar amilosa 23\%, Ciherang 23\%, IR64 23\%, Cimelati 19\% dan Inpari21 26\%. Haryadi (2010) menyatakan bahwa secara umum, kandungan amilosa dibagi menjadi empat golongan, yaitu amilosa rendah $(<20 \%)$, sedang (20-25\%), agak tinggi (25 $27 \%$ ), dan tinggi (>27\%). Boror (1992) dalam Zulfahnur (2010) menyatakan bahwa kandungan amilosa yang tinggi pada beras berpengaruh terhadap sifat antifeedant, dimana sifat ini mempengaruhi selera makan bagi induk pada masa infestasi atau saat stadium larva. Tetapi berdasarkan hasil pengamatan kemunculan imago tertinggi pada beras dari varietas Inpari21 yang memiliki kadar amilosa agak tinggi dengan rata-rata populasi akhir 184 ekor dengan susut bobot 2,23\%, sedangkan populasi terendah pada beras dari varietas IR64 yang memiliki kadar amilosa sedang 64,67 ekor dengan susut bobot 0,71\%. Zulfahnur (2010) menyatakan bahwa kadar amilosa bukanlah satu-satunya faktor yang mempengaruhi resistensi beras uji, dalam penelitiannya menunjukan bahwa beras varietas Membramo dengan kadar amilosa paling rendah 19,00\% merupakan beras varietas yang paling rentan dibandingkan dengan beras lainnya. Tetapi hasil penelitiannya menunjukan hal yang berlainan. Beras varietas Batutegi dengan kadar amilosa $22,30 \%$ merupakan beras yang paling rentan terhadap serangan $S$. zeamais. Hal ini diduga bahwa faktor kadar air, ukuran butiran, kekerasan butiran beras berpengaruh pada kemunculan populasi imago baru. Seperti yang dinyatakan oleh Pasaribu (2009) bahwa selain komponen kimia pada beras seperti amilosa dan protein, butiran mengapur dipercaya mempengaruhi ketahanan terhadap serangan hama pascapanen.

Tabel 4. Presentase Penurunan Berat Pakan pada 5 Jenis Beras Selama 8 minggu Penyimpanan.

\begin{tabular}{lc}
\hline Jenis Beras & Rata-rata $(\%)$ \\
\hline Inpari 21 & $2, .23$ \\
Mekongga & 1,60 \\
Ciherang & 1,49 \\
Cimelati & 0,86 \\
IR64 & 0,71 \\
\hline
\end{tabular}

\section{KESIMPULAN}

Berdasarkan hasil penelitian dan pembahasan makadapatdisimpulkanbahwaPopulasi imago Sitophilus oryzae paling tinggi pada jenis beras Inpari21, sedangkan populasi rendah pada jenis beras Cimelati, Mekongga, Ciherang dan IR64.

\section{DAFTAR PUSTAKA}

Antika, S.R.V., L.P. Astuti, dan R. Rachmawati. 2014. Perkembagan Sitophilus oryzae Linnaeus
(Coleptera: Curculionidae) pada berbagai jenis pakan. Jurnal HPT 2: 2338 - 4336

Haryadi. 2008. Teknologi Pengolahan Beras. Gadjah Mada University Press. Yogyakarta. 240p.

Herlina, L. dan B. Istiaji. 2013. Respons ketahanan beberapa varietas gandum terhadap hama gudang Sitophilus zeamais (Coleoptera: Dryophthoridae). Buletin Plasma Nutfah 19:2.

Kamsiati, E., E. Darmawati, dan Y. Haryadi. 2013. Screening varietas lokal Kalimantan Tengah terhadapserangan Sitophlus oryzae selama penyimpanan. Jurnal Pangan 22: 345-356.

Lopulalan, C.G.C. 2010. Analisa ketahanan beberapa varietas padi terhadap serangan hama gudang Sitophilus Oryzae. Jurnal Budidaya Pertanian 6: 11-16.

Manueke, J. dan J. Pelealu. 2015. Ketertarikan hama Sitophilus oryzae pada beras, jagung, pipilan kacang tanah, kacang kedelai, dan kopra. Jurnal Eugenia 21:2.

Pasaribu, M.J. 2009. Pertumbuhan Populasi Sitophilus zeamais Motsch (Coleoptera: Curculonidae) Pada Empat Kultivar Beras. Skripsi. Institut Pertanian Bogor.

Pertiwi, T.U.W. 2011. Kualitas Sensoris dan Penghambatan Kontaminasi insekta Beras Organik Mentikwangi dengan Berbagai Jenis Pengemas Selama Penyimpanan. Skripsi. Surakarta: Universitas Sebelas Maret Surakarta.

Sastrasupradi, A. 2000. Rancangan Percobaan Praktis Bidang Pertanian. Edisi revisi. Kanisius. Yogyakarta. Hlm 37-38.

Sodiq, M. 2009. Ketahanan Tanaman Terhadap Hama. UPN Press. Surabaya. 79p.

Titahena, M.L.J. dan D. Febriyanti. 2015. Penerpan PTT Padi Mendukung Swasembada Pangan di Maluku. BPTP Maluku. Ambon. 20p.

Wulandari, S., S. Oemry, dan Y. Pangestiningsih. 2014. Pengaruh tekstur butiran pada beberapa komoditas terhadap jumlah imago hama Sitophilus oryzae L. (Coleoptera: Curculionidae) di laboratorium. Jurnal Online Agroekoteknologi 2: 1189-1195.

Yasin, M. 2009. Kemampuan Akses Makan Serangga Hama Kumbang Bubuk dan Faktor Fisikokimia yang Mempengaruhinya. Prosiding Seminar Nasional Serealia.

Yudansha, A., T. Himawan, dan L.P. Astuti. 2013. Perkembangan dan pertumbuhan Sitophilus oryzae L. (Coleoptera: Curculionidae) pada beberapa jenis beras dengan kelembaban lingkungan yang berbeda. Jurnal HPT 1: 23384336.

Zulfahnur. 2010. Kajian Resistensi Lima Jenis Beras Varietas Lokal Terhadap Serangan Sitophilus Zeamais Motsch. Skripsi. Institut Pertanian Bogor. 